\title{
Obraz czarownicy w najnowszej polskiej historiografii procesów o czary w czasach wczesnonowożytnych
}

\section{Summary \\ The image of the witch-woman in the recent Polish historiography of the witch trials during the early modern period}

In the paper the author intended to characterize the image of the witch-woman, as it is shown by the Polish historiography of the witch trials during the early modern period, in the light of the current studies, focusing on the female one. In this context, a number of questions present themselves and one of the purposes of this article is to find answers to the following questions, i.e.: on which factors research focus, while characterizing women accused of the witchcraft; was accusing of the doing evil and cooperation with the devil connected with the particular variables (sex, biological feature of a woman), or was it rather an outcome of the belonging to the particular social group, or maybe even a result of the economic situation in those days. In this article there is also raised a question: how much the recent findings overthrow the stereotype of the witch, which is consolidated in the folk memory of the citizens of Poland. The concepts presented in the following paper are intended to be the starting point of the discussion about the said problem. According to that, this article is not the review of the research focused on magic, witchcraft or witch trials, nor the summary of the Catholic Church attitude, which was widely discussed in the past research papers.

Keywords: woman, witch, trials, witchcraft, historiography

\section{Streszczenie}

W artykule podjęto próbę charakterystyki obrazu kobiety-czarownicy, jaki wyłania się w polskiej historiografii procesów o czary toczących się w dobie wczesnonowożytnej w świetle prowadzonych badań nad niewiastą. W tym kontekście nasuwa się szereg pytań, na które próbowano udzielić odpowiedzi w artykule, m.in.: na jakie czynniki zwracają uwagę badacze charakteryzujący kobiety oskarżone o czary, czy posądzenie o czynienie zła i spółkowanie z diabłem uzależnione było od konkretnych czynników (płci, funkcji biologicznych kobiety), czy raczej wynikało z przynależności do konkretnej grupy społecznej, bądź też warunkowane było sytuacją gospodarczą, w jakiej przyszło żyć oskarżonym. Postawiono również pytanie, 
na ile dotychczasowe ustalenia obalają stereotyp czarownicy utrwalony w zbiorowej pamięci mieszkańców Rzeczypospolitej. Prezentowane rozważania stanowią punkt wyjścia do dalszej dyskusji w zakresie analizowanego problemu. Nie stanowi on zatem przeglądu czy też rewizji badań nad magią, czarami i procesami, a także stanowiska Kościoła katolickiego, które szeroko zostało omówione w dotychczasowych pracach.

Słowa kluczowe: kobieta, czarownica, procesy, czary, historiografia

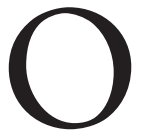

braz czarownicy w zbiorowej pamięci oscyluje wokół dwóch przeciwstawnych wizerunków: z jednej strony starej, pozbawionej urody, mającej niecne zamiary kobiety, z drugiej zaś pięknej, kuszącej swym wdziękiem, a przez to prowadzącej do zguby dziewczyny. Powstał on, jak słusznie zauważyła Danuta Kowalewska, w wyniku zaistnienia kilku czynników, głównie tradycji literackiej oraz reliktów dawnych wierzeń ${ }^{1}$. O kobiecie możemy powiedzieć, że była ona postrzegana dwojako, tj. jako dobra lub zła, jako pobożna lub grzesznica. Najlepszym tego przykładem jest biblijna Ewa, która z jednej strony rysuje się nam jako ta sięgająca po zakazany owoc w raju, czyli ściągająca na ludzkość cierpienie i śmierć, z drugiej zaś jako matka, rodzicielka ludzkości.

W ciągu ostatnich kilkudziesięciu lat tematyka polskich procesów o czary w czasach wczesnonowożytnych cieszyła się dużym zainteresowaniem nie tylko historyków, lecz także badaczy innych dziedzin². Wraz z nastaniem lat dwutysięcznych obserwujemy wzrost badań nad czarownictwem ${ }^{3}$ oraz pokrewnymi mu zjawiskami

1 Cf. D. Kowalewska, Czarownica w literaturze polskiego oświecenia. Stereotyp i pteć, „Acta Universitatis Lodziensis. Folia Litteraria Polonica" 2016, t. IV(XXXIV), s. 53.

2 Stan polskich badań po zakończeniu pierwszej wojny światowej został omówiony przez Ł. Hajdrycha, Polska historiografia procesówo czary. Zarys problemu, „Historia@Teoria” 2017, nr 2(4), s. 209-221. Autor zaznaczył jednak, że na problematykę polowań na czarownice zwrócono uwagę już w XIX w.

3 S. Salmonowicz, Procesy o czary w Polsce. Próba rozważań modelowych, [w:] Prawo wczoraj i dziś. Studia dedykowane profesor Katarzynie Sójce-Zielińskiej, red. G. Bałtruszajtys, Warszawa 2000, s. 303-321; M. Pilaszek, Litewskie procesy czarownic w XVI-XVIII w., „Odrodzenie i Reformacja w Polsce” 2002, t. XLVI, s. 7-35; eadem, Procesy o czary w Polsce w wiekach XV-XVIII, Kraków 2008; J. Wijaczka, Procesy o czary w regionie świętokrzyskim w XVII-XVIII wieku, [w:] Z przesztości regionu świętokrzyskiego od XVI do XX wieku, red. idem, Kielce 2003, s. 37-72; idem, Mężczyźni jako ofiary procesów o czary przed sądem tobżenickim $w$ drugiej potowie XVIII wieku, „Czasy Nowożytne” 2004, t. XVII, s. 17-30; idem, Proces o czary we wsi Mtotkowo w 1692 roku. Przyczynek do polowania na czarownice $w$ Rzeczypospolitej z XVII wieku, „Odrodzenie i Reformacja w Polsce” 2004, t. XLVII, s. 161-170; idem, Procesy o czary w Polsce w dobie Oświecenia. Zarys problematyki, „Klio” 2005, t. VII, s. 17-62; idem, Procesy o czary w Prusach Ksiażęcych (Brandenburskich) w XVI-XVIII wieku, Torun 2007; idem, Magia i czary. Polowanie na czarownice i czarowników w Prusach Ksiażęcych $w$ czasach wczesnonowożytnych, Toruń 2008; idem, Proces o czary we wsi Osowo z 1686 roku, „Czasy Nowożytne” 2011, t. XXIV, s. 221-230; idem, Oskarżenia i procesy o czary w Kózminie w XVII-XVIII wieku, „Roczniki Historyczne" 2016, t. LXXXII, s. 197-219; idem, Próba zimnej wody (ptawienie) w oskarżeniach i procesach o czary w państwie polsko-litewskim w XVI-XVIII wieku, „Odrodzenie i Reformacja w Polsce” 2016, t. LX, s. 73-110; idem, Procesy o czary przed sadem sottysim Kowalewa (Pomorskiego) w XVII-XVIII wieku, „Zapiski Historyczne” 2017, t. LXXXII, z. 2, s. 101-119; idem, Procesy o czary w Wielkopolsce w XVI-XVIII wieku, „Czas Przeszły. Poznańskie Studia Historyczne” 2017, t. IV, s. 177-190; idem, 
magiczno-demonologicznymi ${ }^{4}$. Zbiegają się one z intensyfikacją badań nad kobietą, głównie z kręgów szlacheckich, jej pozycją oraz rolą w rodzinie i społeczeństwie w czasach wczesnonowożytnych ${ }^{5}$. Na kartach monografii i artykułów traktujących o cza-

Procesy o czary w Królewcu $w$ XVI-XVIII wieku, [w:] Zjawiska magiczno-demoniczne na terenie dawnych ziem pruskich na tle porównawczym, red. K. Grążawski, t. II, Olsztyn 2019, s. 207-221; idem, Procesy o czary w Gdańsku w XVI-XVII wieku, „Przegląd Historyczny” 2019, t. CX, z. 3, s. 399-417; idem, Próba zimnej wody (ptawienie) w procesach o czary we wczesnonowożytnej Europie, „Klio” 2020, t. LIII, nr 2, s. 19-66; idem, „Czarownice” w dobrach miejskich Gdan'ska w czasach wczesnonowożytnych, [w:] Kobiety w Prusach Królewskich, red. W. Zawadzki, Pelplin 2020, s. 39-54; T. Wiślicz, Zarobić na duszne zbawienie. Religijność chtopów matopolskich od potowy XVI do końca XVIII wieku, Warszawa 2001, s. 161-199; idem, Igraszki z diabtem. Procesy o czary w Rzeczypospolitej, [w:] Sekrety historii Polski. Tego nie uczyli nas w szkole, red. Z. Klimaszewska, Warszawa 2003, s. 174-177; idem, Spoteczeństwo Kleczewa i okolic w walce z czartem (1624-1700), „Kwartalnik Historyczny” 2004, nr 2, s. 37-60; idem, The Township of Kleczew and Its Neighbourhood Fighting the Devil (1624-1700), „Acta Poloniae Historica" 2004, t. LXXXIX, s. 65-95; idem, Tto spoteczne procesów o czary w Kleczewie i okolicy. Próba ujęcia liczbowego, [w:] Cywilizacja prowincji Rzeczypospolitej szlacheckiej, red. A. Jankowski, A. Klonder, Bydgoszcz 2004, s. 229-244; idem, Talking to the Devil in the Early Modern Popular Imagination, [w:] Faith and Fantasy in the Renaissance. Texts, Images, and Religious Practices, eds O. Zorzi Pugliese, E.M. Kavaler, Toronto 2009, s. 135-146; M. Ostling, Nieznany proces o czary i świętokradztwo w Lublinie w 1644 roku, „Lud” 2005, t. LXXXIX, s. 191-203; W. Wyporska, Witchcraft in Early Modern Poland, 1500-1800, London 2013; D. Kowalewska, Magia i astrologia w literaturze polskiego oświecenia, Torun 2009; M. Moeglich, Procesy o czary przed sądem miejskim wagrowieckim chronologia i dynamika zjawiska, [w:] Wangrovieciana studia et fontes. Wagrowieckie studia muzealne, red. M. Moeglich, M. Krzepkowski, t. III, Wągrowiec 2016, s. 44-91; M. Sawicki, Czarownica oczami litewskiej szlachty. Dwa procesy o czary w Wielkim Księstwie Litewskim w 1631 i 1641 r., [w:] Staropolski ogląd świata. Sarmacki sensualizm, red. F. Wolański, Toruń 2017, s. 59-73; A. Odrzywolska, Praktyki magiczne w XVI w. i ich kontekst kulturowy, „Klio” 2020, t. LIII, nr 2, s. 107-132; A. Ziober, Spoteczno-ekonomiczne uwarunkowania oskarżeń o czary w Wielkim Księstwie Litewskim w XVII wieku. Przyczynek do badań, ibidem, s. 133-150; P. Klint, Mitość, mężobójstwo i praktyki magiczne. Analiza zeznań $i$ wyroku w sprawie o czary przed sadem miejskim w Sanoku z 1657 r., ibidem, s. 183-198; Ł. Hajdrych, Przemoc wobec kobiet a procesy o czary w Kleczewie w latach 1624-1629, „Rocznik Leszczyński” 2017, t. XVII, s. 41-52; idem, Procesy o czary przed sądem wójtowskim miasta Żerkowa w pierwszej potowie XVIII w., „Klio” 2020, t. LIII, nr 2, s. 247-258; B. Marcińczak, Między tacnowiernościq a niewiernościq. Diabet, magia i czary w „Nowych Atenach” $i$ „Diable w swojej postaci”, Warszawa 2014.

4 Jest to niejako odpowiedź na apel wystosowany przez Kazimierza Sochaniewicza podczas XII Zjazdu Lekarzy i Przyrodników w Warszawie w 1925 r., w którym zwrócił on uwagę na konieczność wydawania materiałów źródłowych, a także powstawania prac, w których podjęto by próbę całościowego ujęcia tematu. Vide: K. Sochaniewicz, O potrzebie systematycznego wydawnictwa materiatów do historii procesów o czary w Polsce: referat wygtoszony na XII Zjeździe Lekarzy i Przyrodników w Warszawie, „Lud” 1925, t. XXIV, s. 165-166. Vide również: S. Bylina, Magia, czary i kultura ludowa w Polsce XV i XVI w., „Odrodzenie i Reformacja w Polsce” 1990, t. XXXV, s. 39-52; Z. Osiński, Zabobon, przesą, diabty, czarownice i wilkotaki w pamiętnikach polskich z XVI i XVII wieku, „Annales Universitatis Mariae Curie-Skłodowska, sectio F - Historia” 2003, vol. LVIII, s. 59-72; Zjawiska magiczno-demoniczne na terenie dawnych ziem pruskich na tle porównawczym, red. K. Grążawski, J. Gancewski, Olsztyn 2015; Czary, alchemia, opętanie w kulturze na przestrzeni stuleci. Studia przypadków, red. J. Pietrzak-Thebault, Ł. Cybulski, Warszawa 2015.

5 M. Bogucka, Problematyka genderowa w perspektywie europejskiej, [w:] Per mulierem... Kobieta w dawnej Polsce - wśredniowieczu i w dobie staropolskiej, red. K. Justyniarska-Chojak, S. Konarska-Zimnicka, 
rach, innych zjawiskach demonologicznych oraz toczonych z tego powodu procesach, oprócz analizy zagadnień związanych z dynamiką rozwoju zjawiska w czasie i przestrzeni, uwarunkowaniami prawnymi, specyfiką społeczną, mentalną, religijną, a także gospodarczą, coraz częściej odnajdujemy rozważania dotyczące kobiety - tego, jak była ona postrzegana jako czarownica. I choć przedstawicielkom „płci pięknej”, częściej niż mężczyznom, zarzucano posługiwanie się czarami, to najnowsze ustalenia dowodzą, że w niektórych państwach europejskich oskarżenia padały równie często pod adresem płci męskiej'.

Warszawa 2012, s. 13-25; eadem, Biatogtowa $w$ dawnej Polsce: kobieta $w$ spoteczeństwie polskim XVIXVIII wieku na tle porównawczym, Warszawa 1998; eadem, Gorsza pteć. Kobieta w dziejach Europy od antyku po wiek XXI, Warszawa 2006; B. Popiołek, Kobiecy świat w czasach Augusta III. Studia z mentalności kobiet z kręgów szlacheckich, Kraków 2003; Kobiece kregi korespondencyjne w XVII-XIX wieku, red. B. Popiołek, U. Kicińska, A. Słaby, Warszawa 2016; Kobieta i mężczyzna: jedna przestrzeń - dwa swiaty, red. B. Popiołek, A. Chłosta-Sikorska, M. Gadocha, Warszawa 2015; A. Jakuboszczak, Rodzina i rodzinność szlachcianek wielkopolskich w XVIII wieku. Perspektywa kobieca, Poznań 2016; eadem, Matka - córka - siostra. O intymności i prywatności w kobiecych relacjach w świetle korespondencji wielkopolskich rodzin szlacheckich (XVIII wiek), [w:] Publiczne, prywatne, intymne w kulturze XVIII wieku, red. T. Kostkiewiczowa, Warszawa 2014, s. 147-159; eadem, Panny i wdowy - w poszukiwaniu wtasnej przestrzeni. Losy osiemnastowiecznych szlachcianek z kregu rodziny Dziatyńskich, [w:] Kobieta i mężczyzna..., s. 395-405; eadem, Żona i matka przewodniczkami w życiu duchowym? Rola kobiety w budowaniu przestrzeni sacrum i profanum w XVIII w., [w:] Staropolski oglad świata. Problemy kultury staropolskiej, poszukiwanie sacrum odnajdywanie profanum, red. B. Rok, F. Wolański, Toruń 2012, s. 345-355; H. Dziechcińska, Kobieta w żciu i literaturze XVI i XVII wieku, Warszawa 2001; M. Malinowska, Sytuacja kobiety w siedemnastowiecznej Francji i Polsce, Warszawa 2008; B. Judkowiak, Franciszka Urszula Radziwittowa - w poszukiwaniu wtasnego gtosu: propozycje interpretacyjne, dokumentacyjne i edytorskie, Poznań 2013. Vide także prace innych badaczek: E. Dubas-Urwanowicz, O prawie w świecie kobiet - szlachcianek w Rzeczypospolitej w XVI-XVII wieku, [w:] Kobieta i mężczyzna..., s. 57-72; eadem, Magnackie matżeństwa mieszane $w$ Wielkim Księstwie Litewskim $w$ XVI-XVII w., [w:] Wta$d z a$ i prestiz. Magnateria Rzeczypospolitej $w$ XVI-XVIII wieku, red. J. Urwanowicz, przy współudziale E. Dubas-Urwanowicz, P. Guzowskiego, Białystok 2003, s. 561-586. Vide też: R. Gałaj-Dempiak, Migracje kobiet zamężnych $w$ świetle pamiętników staropolskich pisanych przez szlachtę, [w:] Kobiety iprocesy migracyjne, red. A. Chlebowska, K. Sierakowska, Warszawa 2010, s. 29-46; Ł. Charewiczowa, Kobieta w dawnej Polsce. Do okresu rozbiorów, Poznań 2002; K. Targosz, Sawantki w Polsce XVII w. Aspiracje intelektualne kobiet ze środowisk dworskich, Warszawa 1997; B. Manyś, Radości i troski Anny z Mycielskich Radziwittowej w listach do męża Michata Kazimierza Radziwitta „Rybeńki”, [w:] Kobiece kregi korespondencyjne..., s. 171-185; eadem, „Jak się ty tam dziś będziesz weselić, to i ja tu będę wesota”. O świętach i świętowaniu w korespondencji Anny z Mycielskich Radziwittowej z lat 1754-1762, [w:] Staropolski ogląd świata. Nulla dies sine linea. Ksiega jubileuszowa dedykowana profesorowi Bogdanowi Rokowi w 70. rocznicę urodzin, red. E. Kościk, F. Wolański, R. Żerelik, Toruń 2017, s. 159-172; B. Manyś, A. Jakuboszczak, Obraz matżeństwa Anny z Mycielskich i Michata Kazimierza Radziwitta „Rybeńki” w listach „drugiejpani na Nieświeżu” z lat 1754-1762, [w:] Wokót Wielkiego Księstwa Litewskiego i jego tradycji, red. B. Manyś, M. Zwierzykowski, Poznań 2016, s. 185-200; eadem, Relacje Anny z Mycielskich z dziećmi w świetle listów „drugiejpani na Nieświeżu” z lat 1754-1762, „Acta Anniversaria” 2017, t. III, s. 38-54; B. Popiołek, Dobrodziejki i klienci. Specyfika patronatu kobiecego i relacji klientalnych w czasach saskich, Wilanów 2020 (tam też zebrano obfitą najnowszą literaturę przedmiotu).

6 Wielkość zjawiska ukazał Jacek Wijaczka w pracy poświęconej procesom o czary w Prusach Książęcych, zestawiając $\mathrm{w}$ dwóch tabelach skalę oskarżeń wysuwanych wobec kobiet i mężczyzn. 
Nasuwa się więc pytanie, jaki obraz kobiety parającej się czarami wyłania się w polskiej historiografii procesów o czary toczących się w okresie wczesnonowożytnym w świetle prowadzonych badań nad niewiastą? Na jakie czynniki zwracają uwagę badacze charakteryzujący kobiety oskarżone o czary? Czy posądzenie o czynienie zła i spółkowanie z diabłem uzależnione było od konkretnych czynników, takich jak płeć i funkcje biologiczne kobiety, czy może wynikało również z przynależności do konkretnej grupy społecznej albo też z sytuacji gospodarczej, w jakiej przyszło żyć oskarżonym? Należy postawić pytanie, na ile dotychczasowe ustalenia obalają stereotyp czarownicy utrwalony w zbiorowej pamięci mieszkańców Rzeczypospolitej. W tym artykule podjęłam próbę odpowiedzi na te i inne pytania. Dodać należy, że rozważania te stanowią punkt wyjścia do dalszej dyskusji w zakresie analizowanego problemu. $\mathrm{Na}$ próżno zatem doszukiwać się w nim przeglądu lub rewizji badań nad magią, czarami i procesami, a także stanowiska Kościoła katolickiego, które szeroko zostało omówione w pracy autorstwa Jacka Wijaczki ${ }^{7}$.

W analizowanej literaturze przedmiotu, czyli tej powstałej po 2000 r., rozważania o czarownicy osadzone są w kontekst opinii będących w obiegu w XVI-XVIII stuleciu. ${ }^{8}$ Takie podejście do problemu z jednej strony wydaje się słuszne, gdyż wiedza o tym, jak była ona postrzegana przez ówcześnie żyjących jest ważna, z drugiej jednak czytelnik odnosi wrażenie, że nie poddaje się większej refleksji czynników, które decydowały o percepcji przez społeczeństwo kobiety jako czarownicy. Na tle dotychczasowych ustaleń interesujące wydają się rozważania wspomnianej Danuty Kowalewskiej, która dokonując analizy obrazu czarownic w polskim piśmiennictwie oświeceniowym, spojrzała na nie przez pryzmat płci oraz stereotypu, w jaki została wpisana kobieta wyglądająca w określony sposób albo będąca niewydolną społecznie?.

Z koncepcji interpretacyjnych wskazanych przez badaczkę żywo obecne w literaturze traktującej o czarach są co najmniej dwie. Pierwsza z nich wiąże się z postrzeganiem kobiety parającej się czarami jako tej, która świadomie podejmowała „współpracę” z szatanem, wchodziła z nim w relacje, stając się jego "prawą ręką" do czynienia zła. Takie postrzeganie niewiasty było skutkiem działalności kaznodziejów, którzy ów obraz

Vide: J. Wijaczka, Procesy o czary w Prusach Ksiażęcych..., s. 79, tab. 3; s. 104, tab. 4. Vide też: idem, Mężczyźni jako ofiary..., s. 17-18. Małgorzata Pilaszek podała, że około 90\% oskarżonych to kobiety. Jak stwierdziła badaczka, były one bardziej narażone niż mężczyźni „przez sam fakt bycia kobietą”. Dalej wyjaśniła, że w myśl ówcześnie żyjących zdesperowany mężczyzna był skory do użycia jedynie siły fizycznej, sfrustrowana kobieta zaś nie wahała się użyć czarów. Vide: M. Pilaszek, Procesy o czary w Polsce..., s. 396. Vide: A. Karpiński, Kobieta w mieście polskim w drugiej potowie XVI i w XVII wieku, Warszawa 1995, s. 320; D. Kowalewska, Czarownica w literaturze..., s. 56. Vide też: R. Schulte, Man as Witch: Male Witches in Central Europe, New York 2009.

$7 \quad$ J. Wijaczka, Kościót wobec czarów..., s. 275-302 (tam też zebrana stosowna literatura).

8 M. Pilaszek, Procesy o czary w Polsce..., s. 398; J. Wijaczka, Procesy o czary w Prusach Ksiązęcych..., s. 78, przyp. 152-154. Vide też: M. Ostling, Between the Devil and the Host. Imagining Witchcraft in Early Modern Poland, Oxford 2011.

9 D. Kowalewska, Czarownica w literaturze..., s. 57. 
implikowali w kazaniach wygłaszanych z ambony („opowieściach”), i to nie tylko niepotrafiącej czytać społeczności miejskiej i wiejskiej. Często poruszano w nich sprawy trudnej codzienności, utożsamiając czarostwo $\mathrm{z}$ antyreligią ${ }^{10}$. To zaś przyczyniło się do pewnego określonego sposobu postrzegania czarownicy.

Jak wskazują badacze zajmujący się problematyką czarownictwa, w „zbiorowym portrecie polskich czarownic" najczęściej widziano kobiety stare, które mogły być zarówno pannami, jak i wdowami lub mężatkami ${ }^{11}$. Zwracają oni uwagę, że według zeznań świadków charakteryzowały się one złośliwym, mściwym oraz zazdrosnym usposobieniem ${ }^{12}$. Wykluczenie z jakiś powodów ze społeczności lokalnej, „trwające wdowieństwo"13 albo też problemy natury egzystencjalnej sprawiały, że kobiety te stroniły od kontaktu z innymi ludźmi. Zamykając się w sobie, lub też będąc izolowanymi przez społeczeństwo lokalne, poszukiwały dla siebie przestrzeni, w której mogłyby zaznać spokoju i stać się anonimowe. Te cechy, w połączeniu z wizerunkiem postarzałej, zaniedbanej kobiety, sprawiały, że wśród współmieszkańców miast, miasteczek i wsi kiełkowała myśl, iż pośród nich mieszkała czarownica, uczestnicząca w sabacie, występująca przeciw Kościołowi i oddająca się dziwacznym praktykom seksualnym ${ }^{14}$. I choć takie ujmowanie problemu było częściej spotykane w XV i XVI w., to w kolejnych stuleciach implikowanie społeczeństwu takiego obrazu czarownic nadal było żywo praktykowane zarówno przez katolickich duchownych, jak i przez wykształconą oraz oczytaną szlachtę ${ }^{15}$.

10 Ibidem, s. 57. O podejściu Kościoła do magii i czarów vide: J. Wijaczka, Kościót wobec czarów..., s. 80-82. Cf. J. Węglorz, Zdrowie, choroba i lecznictwo w spoteczeństwie Rzeczypospolitej XVI-XVIII wieku, Toruń 2015, s. 271-276. Vide też: M. Sawicki, „Co to sq czary? Co za znaki ich?”. Litewskie kazanie i sposoby na czary z końca XVII i XVIII w., „Studia Historyczne” 2018, t. LXI, z. 3(243), s. 18; M. Bogucka, Gorsza pté́..., s. 171.

11 Cf. A. Karpiński, op. cit., s. 320.

12 Cf.J. Wijaczka, Procesy o czary w Prusach Książęcych..., s. 78-79.

13 Jak zauważył Cezary Kuklo, niezamożne lub też obarczone liczniejszym potomstwem owdowiałe kobiety miały dużo mniejsze szanse ponownego zamążpójścia. To zaś było niezwykle upragnione, gdyż śmierć współmałżonka przekształcała komórkę społeczną w rodzinę niepełną. Ponadto, jak dodał badacz, dążono do odbudowy rodziny pełnej, w mieście preindustrialnym właśnie na niej opartych było wiele działań gospodarczych. Vide: C. Kuklo, Kobieta samotna w spoteczeństwie miejskim u schytku Rzeczypospolitej szlacheckiej, Białystok 1998, s. 147-150. Swoistą „opieką” wdowy zostały otoczone przez Kościół katolicki, który nie mógł wobec nich pozostać obojętny. Więcej na ten temat: A. Jakuboszczak, Wdowa i wdowieństwo w świetle osiemnastowiecznych tekstów religijnych, „Nasza Przeszłośc” 2010, t. CXIII, s. 252 i n.

14 Małgorzata Pilaszek odwołała się do badań Marii Boguckiej, wskazując za badaczką, że wraz z penalizacją prostytucji wszystkie kobiety były napiętnowane stygmatem „nieczystego seksu” (M. Pilaszek, Procesy o czary w Polsce..., s. 394, 398). Cf. A. Karpiński, op. cit., s. 319. Według Jacka Wijaczki (Procesy o czary w Prusach Ksiązęcych..., s. 92-93) mężczyźni nie byli obwiniani o dewiacje seksualne w takim stopniu jak kobiety, gdyż przechodzili do obozu diabła, gdy podupadli na wierze, a nie z powodu ciała i seksualności, jak to miały czynić kobiety.

15 D. Kowalewska, Czarownica w literaturze..., s. 57. Cf. M. Pilaszek, Litewskie procesy czarownic..., s. 13-14. Vide też: J. Wijaczka, „Czarownice” w dobrach miejskich Gdańska..., s. 42. 
Jak dowodzą badania Jacka Wijaczki, w analizowanym okresie owszem, o czary oskarżano kobiety starsze, ale równie często oskarżenia wysuwano wobec przedstawicielek „płci pięknej” będących „w sile wieku”"16, „przeciętnych” gospodyń domowych, służących, matek, żon i córek ${ }^{17}$. Cezary Kuklo zauważył, że te niewiasty, które przekroczyły 60 lat, zatem wiek starczy, w miastach, miasteczkach i we wsiach skazane były na życie nie tylko w samotności, lecz także w niezwykle trudnych warunkach społecznych ${ }^{18}$. $\mathrm{Z}$ powodu spadku siły traciły możliwość zarobkowania, która stanowiła podstawę ich egzystencji, to zaś skazywało większość z nich na wegetację̨, zmuszając częstokroć do zachowań odbiegających od ówczesnych norm społecznych, odbieranych przez współmieszkańców jako przejaw działalności złego ducha. Jak zauważyli badacze, kobiety żyjące poza rodziną, czyli też kontrolą mężczyzn, stawały się nieprzystosowane do reguł obyczajowych i zwyczajowych grupy, w której dotąd funkcjonowały ${ }^{20}$. Dotyczyło to zwłaszcza tych samotnych, którym nie udało się ponownie wyjść za mąż. Częściej były one narażone na zarzuty wątpliwej reputacji i gorzej zabezpieczone przez prawo ${ }^{21}$. Kobieta przecież była pozbawiona praw publicznych (nie mogła piastować urzędów i godności oraz teoretycznie występować w charakterze świadka, chociaż praktyka dowodzi, że było inaczej) i politycznych. W obronie jej interesów winien występować mąż, opiekun lub plenipotent ${ }^{22}$. Stereotyp starej panny, który rozwijał się przez wieki, był negatywnie wartościowany ${ }^{23}$. Warto przypomnieć, że już w renesansie wywyższano piękno, hołdowano młodości, niewieściej wrażliwości, subtelności i delikatności. Niemieszczące się w tych normach osoby starsze, a także będące w sile wieku „stare panny” umieszczał poza społeczeństwem.

Badacze analizowanego zagadnienia stwierdzają, że problem oskarżeń o czary dotyczył kobiet, które wywodziły się głównie z niższych warstw społecznych, zwłaszcza $\mathrm{z}$ wiejskiej biedoty, rzadziej zaś z lepiej sytuowanego mieszczaństwa lub ze szlachty ${ }^{24}$. Czarownice odnajdywano więc wśród mieszkanek wsi, miast i małych miasteczek, zwłaszcza w tych o charakterze rolniczym. Taki stan rzeczy, jak wskazał Jacek Wijaczka, wynikał m.in. z niskiej kondycji intelektualnej ich mieszkańców, która zbliżona była do mentalności chłopskiej, mocno opierającej się na wierze w przesądy i zabo-

\footnotetext{
16 J. Wijaczka, Procesy o czary w Prusach Ksiązęcych..., s. 79.

17 Tomasz Wiślicz (Tto spoteczne procesów o czary w Kleczewie..., s. 234-235) wymienił również nastolatki, a nawet dzieci.

18 Badania Cezarego Kukli (op. cit., s. 147) dotyczą epoki oświecenia.

19 Ibidem, s. 147-150.

20 D. Kowalewska, Czarownica w literaturze..., s. 57.

21 C. Kuklo, op. cit., s. 150. Cf. M. Pilaszek, Procesy o czary w Polsce..., s. 397.

22 A. Głowacka-Penczyńska, Kobieta w matych miastach Wielkopolski $w$ drugiej potowie XVI i w XVII wieku, Warszawa 2010, s. 24-26.

23 M. Chollet, Czarownica. Niezwyciężona sita kobiet, przekł. S. Królak, Karków 2019, s. 60-61.

24 M. Pilaszek, Procesy o czary w Polsce..., s. 396. Cf. J. Wijaczka, Procesy o czary w Prusach Ksiazżęcych..., s. 80; A. Karpiński, op. cit., s. 320. Jakub Węglorz (op. cit., s. 273) przywołał przykłady żony burmistrza Zamościa oraz wojewody ruskiego Stefana Czarnieckiego.
} 
bony ${ }^{25}$. W literaturze podkreśla się, że podłożem wysuwanych oskarżeń o trudnienie się czarostwem był najczęściej konflikt handlowy lub rywalizacja w warsztacie rzemieślniczym $^{26}$. Potwierdzają to m.in. badania Tomasza Wiślicza, który analizując społeczeństwo Kleczewa, stwierdził, że wśród oskarżonych bywały również żony rzemieślników i karczmarzy ${ }^{27}$.

Należy zwrócić uwagę, że w świetle protokołów spraw rozpatrywanych przez osiemnastowieczny sąd burmistrzowski i radziecki Wilna, stołecznego miasta Wielkiego Księstwa Litewskiego, kobieta jawi się jako krzykliwa, „podwórkowa” gospodyni, która uciekała się do wyzwisk, gróźb i oczerniania ${ }^{28}$. Nie powinien zatem dziwić fakt, że czarownice określano również mianem „złośnic”, „złoczennic” lub też „złą niewiastą" i „złą białogłową" ${ }^{29}$. Będąc sprowokowaną, doprowadzoną do granic psychicznej wytrzymałości lub zagrożoną utratą tego, co najcenniejsze (życia, rodziny, godności, honoru i majątku), niewiasty dopuszczały się nie tylko przemocy słownej, lecz także fizycznej, która była utożsamiana z męskością ${ }^{30}$. Takie praktyki stanowiły codzienność zarówno mieszczanek, jak i chłopek ${ }^{31}$. Tomasz Wiślicz wskazał, że kobiety w analizowanym okresie były przecież postrzegane jako grupa w całości upośledzona społecznie z uwagi na „ułomność płci swojej”. Taki odbiór przedstawicielek „płci pięknej” wpływał na usprawiedliwianie (do pewnego stopnia) niewłaściwych zachowań, akceptując tym samym niektóre $\mathrm{z}$ ich postępowań ${ }^{32}$.

Małgorzata Pilaszek zwróciła uwagę na to, że w opinii ówcześnie żyjących to zła wola i złośliwości kobiety, która wyrażała się m.in. w kłótliwości, budziły największy niepokój wśród lokalnej społeczności, gdyż motywem działań czarownic była złość utożsamiana z niemalże wrodzoną skłonnością do czynienia zła. Ponadto mogła ona wypełnić ludzki umysł, usta i duszę $3^{33}$. Dla społeczności dużo gorsze od wypowiedzianych

J. Wijaczka, Procesy o czary w Prusach Ksiązęcych..., s. 80.

26 M. Pilaszek, Procesy o czary w Polsce..., s. 396. Badaczka zwróciła uwagę, że o czary bywały również oskarżane gospodynie będące na służbie u księży. Posądzano je o handlowanie świętymi kartkami i sakramentaliami. Wpływ na ich postrzeganie wynikał również z faktu, że: „Dla wiernych granica między magią a religią często była mglista, tym bardziej, że w kościelnych ceremoniach zachowały się elementy magiczne, wzmagane przez teatralną oprawę liturgii” (ibidem).

27 Ustalenia autora zostały poczynione na przykładzie Kleczewa. Vide: T. Wiślicz, Tto spoteczne procesów o czary w Kleczewie..., s. 235.

28 B. Manyś, Codzienne niesnaski, któtnie, awantury i bijatyki - przemoc wśród i wobec wileńskich mieszczanek w pierwszej potowie XVIII wieku. Wstęp do badań, „Rocznik Lituanistyczny” 2019, t. V, s. 200. Małgorzata Pilaszek scharakteryzowała problem kłótliwości mieszkańców Wielkiego Księstwa Litewskiego. Przywołała przykład Ubowej, którą określano jako „niespokojną, swarliwą i nieprzyjemną w obejściu niewiastę". Vide: M. Pilaszek, Litewskie procesy czarownic..., s. 8-9.

29 Eadem, Procesy o czary w Polsce..., s. 70-71.

30 B. Manyś, Codzienne niesnaski, któtnie..., s. 200.

31 O sąsiedzkich kłótniach społeczności wiejskiej oraz wykonywanych podczas nich gestach vide:

T. Wiślicz, Gest obraźliwy na wsi polskiej w XVII i XVIII wieku, „Przegląd Historyczny” 1997, t. LXXXVIII, z. 3-4, s. 423.

32 Ibidem, s. 432.

33 M. Pilaszek, Procesy o czary w Polsce..., s. 70. 
przekleństw były te niezwerbalizowane, gdyż według Jakuba A. Czechowicza „myśli nie widzimy, przymiotów onej ciężko doznajemy"34. Poza tym umysł był oceniany jako najsłabszy element ludzkiego ciała, zatem łatwo było go opętać35. Taki stan rzeczy pozwolił badaczom stwierdzić, że na postrzeganie kobiety jako czarownicy w dużym stopniu miały wpływ jej charakter, brak pokory, gadulstwo, samodzielność oraz tendencje do zazdrości i wywoływania kłótni z sąsiadami ${ }^{36}$. Wszystkie te elementy w jakimś stopniu składały się na kobiecą niezależność, która budziła w społeczeństwie strach i poczucie zagrożenia ${ }^{37}$. Należy pamiętać, że według pedagogów i moralizatorów epoki renesansu i baroku ideałem była kobieta pobożna, wstydliwa, posłuszna najpierw rodzicom, później mężowi, pracowita, oddana, gospodarna, a przede wszystkim małomówna żona oraz matka, a nie próżnująca w karczmach plotkarka, która starała się szukać okazji do wyjścia z domu i w wielu przypadkach nawiązująca pozamałżeńską aktywność seksualną, tak negatywnie ocenianą nie tylko przez społeczność chłopską, lecz także mieszczańskąą ${ }^{38}$ Te "posłuszne” niewiasty często zmagały się z bólem, cierpieniem i upokorzeniem, którego doznawały, stając się ofiarami przemocy domowej, uznawanej w czasach wczesnonowożytnych za sprawę stosunkowo "naturalną"39. Czarostwo stawało się więc w ich rozumieniu ucieczką/narzędziem, za pomocą której/którego chciały się uwolnić od agresywnych mężów, braci, konkubentów, a nawet innych kobiet przebywających w ich gospodarstwie ${ }^{40}$.

Badacze problemu podkreślają, że spojrzenie na kobietę jako na istotę skłonną do wyrządzania zła w życiu, w tym zwłaszcza szkód w zdrowiu oraz dobytku, było w jakimś stopniu wynikiem ogólnej kondycji społeczeństwa, które od XVII w. uwikłane zostało w niemalże ciągłe konflikty, w istotny sposób wpływające na stan gospodarki. Wyniszczenie ziem Rzeczypospolitej przez okupujące je wojska prowadziło do uszczuplenia zasobów gospodarczych mieszkańców, wzrostu cen, a w końcu do zubożenia ludności. Kryzysy demograficzne, choroby i zarazy, które panoszyły się wówczas w Koronie i na

34 J.A. Czechowicz, Klucz do niebieskich pokojów to jest szczera spowiedź w podanym doskonatym pokuty sposobie jawnie pokutującego grzesznika, Toruń 1718, k. Av.

35 M. Sawicki, „Co to sq czary? Co za znaki ich?”..., s. 19.

36 B.P. Levack, Polowanie na czarownice w Europie wczesnonowożytnej, przekł. E. Rutkowski, Wroclaw 2009, s. 178, 204-214. Cf. M. Chollet, op. cit., s. 52-53.

Cf. M. Chollet, op. cit., s. 70, 75-76.

38 M. Pilaszek, Procesy o czary w Polsce..., s. 401. Cf. A. Głowacka-Penczyńska, op. cit., s. 42; T. Wiślicz, Upodobanie. Matżeństwo i zwiazki nieformalne na wsi polskiej XVII-XVIII wieku. Wyobrażenia spoteczne i jednostkowe doświadczenia, Wrocław 2012, s. 197-201; idem, Fabrykacja nierzadnicy, czyli o ofiarach względnej swobody seksualnej na polskiej wsi przedrozbiorowej, „Lud” 2017, t. CI, s. 129-148. Badacz podkreślił, że cudzołóstwo podlegało surowszym karom i przynosiło dużo gorsze konsekwencje niż przedmałżeńska aktywność seksualna ludzi stanu wolnego (kawalerów i panien). Vide: idem, $Z$ zagadnień obyczajowości seksualnej chtopów w Polsce XVI-XVIII wieku. Przyzwolenie i penalizacja, „Lud” 2004, t. LXXXVIII, s. 51-53.

39 Vide: A. Jakuboszczak, Rodzina i rodzinnosśc..., s. 210-211.

40 Tomasz Wiślicz (Upodobanie..., s. 158) podał przykłady kobiet będących oskarżonymi o czary, które w swoich zeznaniach potwierdzały, że te „stosowały” w celu zemsty. 
Litwie, oraz niekorzystne zmiany klimatyczne skutkowały nie tylko brakiem żywności, lecz także pogorszeniem warunków życia ${ }^{41}$. Poczucie braku stabilizacji oraz braku bezpieczeństwa z pewnością odbiły się szerokim echem na poszukiwaniu winnego dramatów rozgrywających się w małych, lokalnych społecznościach - kozła ofiarnego, zgodnie z drugą, socjologiczną koncepcją obecną w literaturze przedmiotu ${ }^{42}$. Małgorzata Pilaszek zaś skonstatowała, że w przypadku Wielkiego Księstwa Litewskiego okres wojen toczonych w XVII w. i nawiedzające te tereny pomory wręcz odwróciły uwagę społeczeństwa od problemu czarownic i na jakiś czas zahamowały ich prześladowanie ${ }^{43}$.

Lista wskazanych w literaturze powodów wysuwanych oskarżeń jest co najmniej imponująca. Kobiety m.in. obarczano winą za kradzieże lub psucie mleka, piwa, pomór zwierząt hodowlanych, sprowadzenie chorób i śmierci, problemy z płodnością, zatruwanie wody i jedzenia, występowanie kataklizmów pogodowych, straty w gospodarce rybnej, sadach i zasiewach, bezczeszczenie hostii oraz dewocjonaliów, uczestnictwo w sabatach i współżycie z szatanem ${ }^{44}$. Strach budziło również przekonanie, że chcąc osiągnąć swój cel, niewiasta mogła przybrać inną formę, zamieniając się np. w kota oraz w białego pieska lub o białej szyi ${ }^{45}$. Badacze potwierdzają, że w wielu przypadkach oddawały się one mało szkodliwym praktykom, które trudno było odróżnić od zwyczajowo przyjętych form zabezpieczania się przed złym losem ${ }^{46}$. Wysunięcie zarzutu czarostwa nie stawało się jednoznaczne z wytoczeniem procesu, jednak niosło ze sobą określone skutki dla osoby obwinionej ${ }^{47}$.

W literaturze podkreśla się, że to, co tajemnicze i niezrozumiałe było z jednej strony utożsamiane z boskością, z drugiej zaś z obecnością sił nadprzyrodzonych, co szczególnie wyeksponowano w epoce baroku ${ }^{48}$. Strach zatem potęgowały nie tylko działania dające konkretny efekt, o czym wspominałam, lecz przede wszystkim praktyki ma-

41 D. Kowalewska, Czarownica w literaturze..., s. 57. Cf. A. Ziober, op. cit., s. 138. Vide: S. Hoszowski, Klęski elementarne $w$ Polsce $w$ latach 1587-1648, [w:] Prace $z$ dziejów Polski feudalnej ofiarowane Romanowi Grodeckiemu w 70. rocznice urodzin, red. Z. Budkowa et al., Warszawa 1960, s. 453-465; P. Miodunka, Kryzysy żywnościowe a anomalie klimatyczne od XVII do potowy XIX wieku na przyktadzie Matopolski, „Historyka. Studia Metodologiczne” 2016, t. XLVI, s. 209-227. O następstwach epidemii XVI-XVIII w. w Rzeczypospolitej pisal: A. Karpiński, $W$ walce $z$ niewidzialnym wrogiem. Epidemie chorób zakaźnych $w$ Rzeczypospolitej $w$ XVI-XVIII wieku i ich następstwa demograficzne, spoteczno-ekonomiczne i polityczne, Warszawa 2000, s. 193-295.

42 A. Ziober, op. cit., s. 138. Maria Bogucka (Gorsza pteć..., s. 171) ponadto wskazała: narodziny kapitalizmu, proletaryzowanie się części chłopstwa, wojny religijne, powstanie państw absolutnych, chęć wzbogacenia się sędziów, urzędników miejskich oraz chęć likwidacji przeciwników politycznych. Vide: M. Pilaszek, Litewskie procesy czarownic..., s. 16-17.

44 A. Karpiński, Kobieta w mieście polskim..., s. 321. Cf. J. Wijaczka, Procesy o czary przed sądem sottysim Kowalewa..., s. 118; M. Sawicki, „Co to sa czary? Co za znaki ich?”..., s. 20.

45 M. Pilaszek, Procesy o czary w Polsce..., s. 410. Vide też: J. Wijaczka, „Czarownice” w dobrach miejskich Gdańska..., s. 42.

46 M. Pilaszek, Litewskie procesy czarownic..., s. 34 .

47 J. Wijaczka, „Czarownice” w dobrach miejskich Gdańska..., s. 41.

48 M. Sawicki, Czarownica oczami litewskiej szlachty..., s. 62. Vide też: J. Węglorz, op. cit., s. 271. 
giczne, do realizacji których wymagano nadprzyrodzonych sił (w tym rzucanie uroków mających przynieść uniesienie miłosne, opętanie niemowląt, wróżenie, odczytywanie znaków na niebie, a także z warunków pogodowych), oraz związane z nimi rytuały i obrzędy. W celu czynienia miłosnych czarów albo zastosowania magii leczniczej niezbędne było, w opinii ówczesnych, przygotowanie specjalnych wywarów, składających się często z trudnych do pozyskania roślin, czy też budzących sporo kontrowersji produktów, takich jak części ciała zwierząt: wyłupione oczy żab, gołębie serca czy zwierzęce kości, psie łajno oraz gotowane mrówki ${ }^{49}$. W tym zakresie badacze zajmujący się ową problematyką zauważyli, że na oskarżenia o czary narażone były zarówno zielarki, jak i akuszerki. Równie często ofiarami oskarżeń padały aptekarki, którym zielarki dostarczały ziół, oraz budzące strach znachorki, otwarcie wskazujące przyczyny chorób i pomagające kobietom ustrzec się ciąży lub rozwiązać tę zagrażającą ich życiu ${ }^{50}$.

Dotychczasowe ustalenia ukazują, że dla społeczności niezrozumiały był rytuał pozyskiwania roślin, wypowiadane podczas niego formuły „zaklęć” oraz wykonywanie wielu gestów mających zwiększyć skuteczność wytworzonych środków, a także prawdopodobieństwo zwalczenia choroby, którą w epoce wczesnonowożytnej nadal postrzegano albo jako szkodliwe działanie sił lub bytów nadprzyrodzonych, albo jako karę za grzechy ${ }^{51}$. W tym celu kobiety musiały dysponować pogłębioną wiedzą leczniczą na temat właściwości zbieranych roślin, wszak często pełniły one funkcję lekarek i pielęgniarek na użytek swojej rodziny i najbliższych ${ }^{52}$. Wśród lokalnej społeczności „karmiącej się" przesądami oraz zabobonami uchodziły za znające odpowiednie praktyki magiczne, rzekomo podnoszące efektywność ich działan ${ }^{53}$. Jak skonstatował Tomasz Wiślicz, wiejskie znachorki bywały tak samo skuteczne jak ówcześni lekarze ${ }^{54}$. Angażowane do pomocy przez szlachtę stawały się zatem „niebezpieczną” konkurencją dla „męskiego świata medycznego", który miał monopol na leczenie od epoki renesansu ${ }^{55}$.

W polskiej historiografii traktującej o problemie czarownic brakuje refleksji nad wyglądem kobiety uznawanej za czarownicę. W tym aspekcie rozważania ograniczają się jedynie do przywołania stereotypowego obrazu, zgodnie z którym jej ciało wyglądało staro, było zdeformowane i uosabiało niespełnienie oraz niepokój ${ }^{56}$. Tymczasem należy pamiętać, że w czasach wczesnonowożytnych kobiece ciało utożsamiane było $\mathrm{z}$ temperamentem, ten zaś zależny był od teorii humoralnej $\mathrm{j}^{57}$. Zgodnie z nią niewiasta

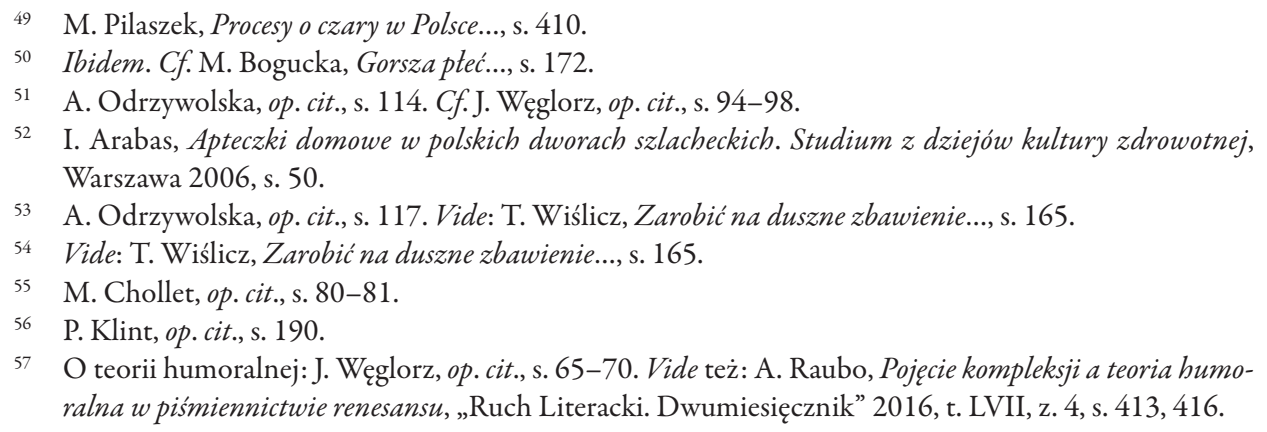

57 O teorii humoralnej: J. Węglorz, op. cit., s. 65-70. Vide też: A. Raubo, Pojęcie kompleksji a teoria humoralna w piśmiennictwie renesansu, „Ruch Literacki. Dwumiesięcznik” 2016, t. LVII, z. 4, s. 413, 416. 
charakteryzowała się „zimnym” i „mokrym” usposobieniem, które było odmienne od męskiego, postrzeganego jako "gorące" $\mathrm{i}$ „suche" 58 . W rezultacie tego w interesującym nas okresie kobiety uznawano za „z natury dumne i rozpustne”, a także „słabego umysłu i rozumu" 59 . Niejaki Johann Bergmann, doktor z Gothy, w jednym z dzieł wydanym w 1629 r. przypisał kobietom następujące przymioty: niestałość, lekkomyślność, kłótliwość i niecierpliwośćc ${ }^{60}$. Niewiasty jawiły się zatem jako przeciwieństwo mężczyzn silnych i inteligentnych. Tym samym ich płeć definiowała je jako dużo mniej odporne na pokusy i bardziej narażone na opętanie przez diabła oraz oddawanie się mu w praktykach seksualnych, zwłaszcza jeśli były wdowami, które miały już rozbudzony apetyt seksualny przez wcześniejsze małżeństwo ${ }^{61}$.

Ponadto w ich ciałach co miesiąc zachodził cykl, który dla ówczesnych medyków wydawał się z jednej strony interesujący, z drugiej zaś tajemniczy i nie do końca zrozumiały ${ }^{62}$. Płodność, choć stanowiła podstawę kobiecości, sprawiała, że niewiasta była postrzegana jako istota o niebezpiecznym potencjale sił nadprzyrodzonych ${ }^{63}$. Niemniej ta, która miesiączkowała, była źródłem przyszłego życia, ale ta, która ich nie miewała, znajdowała się na pograniczu życia i śmierci. Zatem jeśli o czary oskarżano młodą dziewczynę, to uważano, że jej seksualność naznaczona była „piętnem bezpłodności i jałowej erotyki" ${ }^{\prime 4}$.

Należy pamiętać, że zgodnie z ówczesnym myśleniem w ciele kobiety oprócz życia mogły się rozwijać również choroby, które związane były z kobiecym temperamentem, czyli ze wspomnianą teorią humoralną. Według literatury przedmiotu u oskarżonych o czary diagnozowano melancholię, a także szaleństwo, manię i padaczkę. Zgodnie z teorią czterech humorów melancholika charakteryzowała czarna żółć. Od średniowiecza łączono ją z kolorem czarnym. Ta zaś barwa, zwłaszcza w epoce renesansu, miała charakteryzować/określać szatana ${ }^{65}$. Zatem osoba, u której podejrzewano melancholię, była postrzegana jako ta, która ściągnie na okoliczną społeczność złego ducha.

Podsumowując, należy stwierdzić, że najnowsza polska historiografia procesów o czary wyraźnie postępuje w badaniach nad obrazem czarownicy. Wprowadzony do obiegu naukowego bogaty materiał źródłowy pozwala na wyciąganie wniosków, choć

58 M. Lazard, Les avenues de fémynie. Les femmes et la Renaissance, Paris 2001, s. 16-17. Vide też: A. Zdziechiewicz, Obraz kobiety w staropolskich popularnych poradnikach medycznych, „Napis” 2003, seria 9, s. 20.

59 J. Wijaczka, Procesy o czary w Prusach Książęcych..., s. 78, przyp. 152 i 153.

60 Ibidem, s. 78, przyp. 154.

$61 \quad$ T. Wiślicz, Upodobanie..., s. 57. Vide też: idem, Fabrykacja nierzadnicy..., s. 129-148.

62 Jean Astruc (1684-1766) opisał dolegliwości kobiece spowodowane przez menstruację, zamieszczając w pracy analizę jej przyczyn, skutków i objawów. Cf. J. Astruc, Traité des maladies des fermmes, où lom tâché de joindre à une Théorie solide la pratique la plus sûre et la mieux éprouvée, t. I, Paris 1761.

63 J. Węglorz, op. cit., s. 275.

64 M. Pilaszek, Procesy o czary w Polsce..., s. 395.

65 J. Wijaczka, Próba zimnej wody..., s. 36. Vide: J. Lange, Traité des vapeurs, où leur origine, leurs effets et leurs remédes sont mécaniquement expliquez, Paris 1689. Cf. A. Raubo, op. cit., s. 416-417. 
nie w pełni, z uwagi na przeważającą w literaturze przedmiotu narrację rekonstrukcyjną. To sprawia, że w wielu tekstach kobieta parająca się czarami nadal funkcjonuje w sposób anonimowy, mimo że znane jest jej imię i nazwisko.

Niewątpliwie obraz czarownicy wpisany jest w układ zależności społeczno-rodzinnych. Domniemane czarownice jawią się bowiem jako ofiary, które często w wymuszonych ciężkimi torturami zeznaniach opowiadały to, co rodzina, sąsiedzi albo lokalna społeczność chcieli usłyszeć, lub też zaprzeczały wszystkiemu. Obraz ten nie różni się znacząco od ustaleń zagranicznych badaczy ${ }^{66}$. W polskiej historiografii podkreśla się, że tym, co pchało przedstawicielki „płci pięknej” do podejmowania różnych niezrozumiałych i budzących strach działań, były głównie bieda, wykluczenie, dramaty dnia codziennego rozgrywane w ich gospodarstwach. Swą duszę „zaprzedawały diabłu” z głodu, desperacji, chociaż też z trapiącej je melancholiii ${ }^{67}$. Ich płeć, zachodzące w kobiecych ciałach cykle menstruacyjne, podział ról rodzinno-społecznych oraz sztywno określone zachowania stawiały je w konkretnej pozycji do mężczyzn i męskiego świata, w którym przyszło im żyć. To oni bowiem kształtowali ich wizerunek i w dużym stopniu stawali się oprawcami domniemanych czarownic, występując w roli oskarżycieli, świadków i katów. Niewiasty postrzegane były jako słabsze, z uwagi zaś na przypisany im większy popęd seksualny, uważano je za skłonniejsze do uczestniczenia w dziwnych praktykach seksualnych. Ich temperament, niejednokrotnie nadto porywczy, stanowił jedynie dopełnienie obrazu kobiety uważanej za czarownicę, która nie wpisywała się w kanon zachowań społecznych przypisanych niewieście.

Dotychczasowe badania dowodzą również, że społeczeństwo, choć obawiało się praktyk magicznych i działań czarownic, to równie często korzystało z ich usług, kiedy miało do rozwiązania jakieś drobne problemy ${ }^{68}$. W ten sposób z jednej strony akceptowało ich funkcjonowanie we własnych szeregach, z drugiej zaś występowało w roli kata, które w trudnej sytuacji wskazywało kozła ofiarnego.

Oprócz zasygnalizowanych już czynników istotną rolę w kreowaniu obrazu czarownicy odgrywała także kultura ludowa, silnie osadzona w mentalności chłopskiej opartej na wierze w zabobony i gusła. Duży też wpływ miała nauka Kościoła katolickiego, który starając się „umoralnić” społeczność wiejską i miejską, jednocześnie implikował określony obraz czarownicy. W chłopskim świecie, w którym nadrzędnym pragnieniem było osiągnięcie partykularnego celu (np. wyzwolenie się od choroby), spotykały się, a co więcej, w jakimś stopniu także przenikały dwa światy: ten zbudowany

${ }^{66}$ Cf. R. Briggs, Witches and Neighbours. The Social and Cultural Context of European Witchcraft, London 1996; S. Clark, Thinking with demons. The Idea of Witchcraft in Early Modern Europe, Oxford 1999; R. Muchembled, Le Roi et la Sorcière. L'Europe des bûchers XVe-XVIIIe siècle, Paris 1993; L. Roper, Oedipus and the Devil. Witchcraft, Sexuality and Religion in Early Modern Europe, London-New York 1994.

67 M. Pilaszek, Procesy o czary $w$ Polsce..., s. 403-404.

68 P. Klint, op. cit., s. 197. Vide przykład Bartkowej: J. Wijaczka, Oskarżenia i procesy o czary w Koźminie..., s. 202. 
na ortodoksyjnych ceremoniach dewocyjnych oraz ten oparty na zabobonnych zamawianiach $^{69}$. W ich codzienności tajemnicza sfera sacrum przeplatała się zatem ze sferą profanum.

Osobną kwestią pozostaje podwójne oblicze kobiety, Maryi i Ewy, które wyraźnie ukazuje, jak wiele problemów nastręczało kobiece ciało, będące z jednej strony źródłem błogosławionego życia, z drugiej zaś grzechu nieczystości. To drugie spojrzenie implikuje obraz niewiasty bardziej skłonnej do cudzołóstwa, a więc mniej odpornej na działanie złego ducha.

\section{Bibliografia (Bibliography)}

\section{Źródła drukowane}

Astruc J., Traité des maladies des fermmes, où lom tâché de joindre à une Théorie solide la pratique la plus sûre et la mieux éprouvée, t. I, Paris 1761.

Czechowicz J.A., Klucz do niebieskich pokojów to jest szczera spowiedź w podanym doskonatym pokuty sposobie jawnie pokutującego grzesznika, Toruń 1718.

Lange J., Traité des vapeurs, où leur origine, leurs effets et leurs remèdes sont mécaniquement expliquez, Paris 1689.

\section{Opracowania}

Arabas I., Apteczki domowe w polskich dworach szlacheckich. Studium z dziejów kultury zdrowotnej, Warszawa 2006.

Bogucka M., Biatogtowa w dawnej Polsce: kobieta w spoteczeństwie polskim XVI-XVIII wieku na tle porównawczym, Warszawa 1998.

Bogucka M., Gorsza pteć. Kobieta w dziejach Europy od antyku po wiek XXI, Warszawa 2006.

Bogucka M., Problematyka genderowa w perspektywie europejskiej, [w:] Per mulierem... Kobieta w dawnej Polsce - wśredniowieczu i w dobie staropolskiej, red. K. Justyniarska-Chojak, S. Konarska-Zimnicka, Warszawa 2012, s. 13-25.

Briggs Cf. R., Witches and Neighbours. The Social and Cultural Context of European Witchcraft, London 1996.

Bylina S., Magia, czary i kultura ludowa w Polsce XV i XVI w., „Odrodzenie i Reformacja w Polsce" 1990, t. XXXV, s. 39-52.

Charewiczowa Ł., Kobieta w dawnej Polsce. Do okresu rozbiorów, Poznań 2002.

Chollet M., Czarownica. Niezwyciężona sita kobiet, przekł. S. Królak, Karków 2019.

Clark S., Thinking with demons. The Idea of Witchcraft in Early Modern Europe, Oxford 1999.

69 T. Wiślicz, Zarobić na duszne zbawienie..., s. 164. 
Czary, alchemia, opętanie w kulturze na przestrzeni stuleci. Studia przypadków, red. J. Pietrzak-Thebault, Ł. Cybulski, Warszawa 2015.

Dubas-Urwanowicz E., Magnackie matżeństwa mieszane w Wielkim Księstwie Litewskim w XVI-XVII w., [w:] Wtadza i prestiz. Magnateria Rzeczypospolitej w XVI-XVIII wieku, red. J. Urwanowicz, przy współudziale E. Dubas-Urwanowicz i P. Guzowskiego, Białystok 2003, s. 561-586.

Dubas-Urwanowicz E., O prawie w świecie kobiet - szlachcianek w Rzeczypospolitej $w$ XVI-XVII wieku, [w:] Kobieta i mężczyzna: jedna przestrzeń - dwa światy, red. B. Popiołek, A. Chłosta-Sikorska, M. Gadocha, Warszawa 2015, s. 57-72.

Dziechcińska H., Kobieta w życiu i literaturze XVI i XVII wieku, Warszawa 2001.

Gałaj-Dempiak R., Migracje kobiet zamężnych w świetle pamiętników staropolskich pisanych przez szlachte, [w:] Kobiety i procesy migracyjne, red. A. Chlebowska, K. Sierakowska, Warszawa 2010, s. 29-46.

Głowacka-Penczyńska A., Kobieta w matych miastach Wielkopolski w drugiej potowie XVI i w XVII wieku, Warszawa 2010.

Hajdrych Ł., Polska historiografia procesów o czary. Zarys problemu, „Historia@Teoria” 2017, nr 2(4), s. 209-221.

Hajdrych Ł., Procesy o czary przed sądem wójtowskim miasta Żerkowa w pierwszej potowie XVIII w., „Klio” 2020, t. LIII, nr 2, s. 247-258.

Hajdrych Ł., Przemoc wobec kobiet a procesy o czary w Kleczewie w latach 1624-1629, „Rocznik Leszczyński” 2017, t. XVII, s. 41-52.

Hoszowski S., Klęski elementarne w Polsce w latach 1587-1648, [w:] Prace z dziejów Polski feudalnej ofiarowane Romanowi Grodeckiemu w 70. rocznice urodzin, red. Z. Budkowa et al., Warszawa 1960, s. 453-465.

Jakuboszczak A., Matka - córka - siostra. O intymności i prywatności w kobiecych relacjach w świetle korespondencji wielkopolskich rodzin szlacheckich (XVIII wiek), [w:] Publiczne, prywatne, intymne w kulturze XVIII wieku, red. T. Kostkiewiczowa, Warszawa 2014, s. 147-159.

Jakuboszczak A., Panny i wdowy - w poszukiwaniu wtasnej przestrzeni. Losy osiemnastowiecznych szlachcianek z kręgu rodziny Dziatyńskich, [w:] Kobieta i mężczyzna: jedna przestrzeń - dwa światy, red. B. Popiołek, A. Chłosta-Sikorska, M. Gadocha, Warszawa 2015, s. 395-405.

Jakuboszczak A., Rodzina i rodzinność szlachcianek wielkopolskich w XVIII wieku. Perspektywa kobieca, Poznań 2016.

Jakuboszczak A., Wdowa i wdowienstwo w świetle osiemnastowiecznych tekstów religijnych, „Nasza Przeszłość” 2010, t. CXIII, s. 237-246.

Jakuboszczak A., Żona i matka przewodniczkami w życiu duchowym? Rola kobiety $w$ budowaniu przestrzeni sacrum i profanum $w$ XVIII w., [w:] Staropolski oglad świata. Problemy kultury staropolskiej, poszukiwanie sacrum odnajdywanie profanum, red. B. Rok, F. Wolański, Toruń 2012, s. 345-355.

Judkowiak B., Franciszka Urszula Radziwittowa - w poszukiwaniu wtasnego gtosu: propozycje interpretacyjne, dokumentacyjne i edytorskie, Poznań 2013.

Karpiński A., Kobieta w mieście polskim w drugiej potowie XVI i w XVII wieku, Warszawa 1995. 
Karpiński A., W walce z niewidzialnym wrogiem. Epidemie chorób zakaźnych w Rzeczypospolitej $w$ XVI-XVIII wieku i ich następstwa demograficzne, spoteczno-ekonomiczne i polityczne, Warszawa 2000.

Klint P., Mitość, mężobójstwo i praktyki magiczne. Analiza zeznań i wyroku w sprawie o czary przed sądem miejskim w Sanoku z 1657 r., „Klio” 2020, t. LIII, nr 2, s. 183-198.

Kobiece kregi korespondencyjne w XVII-XIX wieku, red. B. Popiołek, U. Kicińska, A. Słaby, Warszawa 2016.

Kobieta i mężczyzna: jedna przestrzeń - dwa światy, red. B. Popiołek, A. Chłosta-Sikorska, M. Gadocha, Warszawa 2015.

Kowalewska D., Czarownica w literaturze polskiego oświecenia. Stereotyp i pteć, „Acta Universitatis Lodziensis. Folia Litteraria Polonica” 2016, t. IV(XXXIV), s. 53-67.

Kowalewska D., Magia i astrologia w literaturze polskiego oświecenia, Toruń 2009.

Kuklo C., Kobieta samotna w spoteczeństwie miejskim u schytku Rzeczypospolitej szlacheckiej, Białystok 1998.

Lazard M., Les avenues de fémynie. Les femmes et la Renaissance, Paris 2001.

Levack B.P., Polowanie na czarownice w Europie wczesnonowożytnej, przekł. E. Rutkowski, Wrocław 2009.

Malinowska M., Sytuacja kobiety w siedemnastowiecznej Francji i Polsce, Warszawa 2008.

Manyś B., "Jak się ty tam dziś będziesz weselić, to i ja tu będę wesota”. O świętach i świętowaniu w korespondencji Anny z Mycielskich Radziwittowej z lat 1754-1762, [w:] Staropolski oglad świata. Nulla dies sine linea. Ksiega jubileuszowa dedykowana profesorowi Bogdanowi Rokowi $w$ 70. rocznicę urodzin, red. E. Kościk, F. Wolański, R. Żerelik, Toruń 2017, s. 159-172.

Manyś B., Codzienne niesnaski, któtnie, awantury i bijatyki - przemoc wśród i wobec wileńskich mieszczanek w pierwszej potowie XVIII wieku. Wstęp do badań, „Rocznik Lituanistyczny” 2019, t. V, s. 193-209.

Manyś B., Radości i troski Anny z Mycielskich Radziwittowej w listach do męża Michata Kazimierza Radziwitta „Rybeńki”, [w:] Kobiece kregi korespondencyjne w XVII-XIX wieku, red. B. Popiołek, U. Kicińska, A. Słaby, Warszawa 2016, s. 171-185.

Manyś B., Relacje Anny z Mycielskich z dziećmi w świetle listów „drugiej pani na Nieświeżu” z lat 1754-1762, „Acta Anniversaria” 2017, t. III, s. 38-54.

Manyś B., Jakuboszczak A., Obraz matżenstwa Anny z Mycielskich i Michata Kazimierza Radziwitta „Rybeńki” w listach „drugiej pani na Nieświeżu” z lat 1754-1762, [w:] Wokót Wielkiego Księstwa Litewskiego i jego tradycji, red. B. Manyś, M. Zwierzykowski, Poznań 2016, s. 185-200.

Marcińczak B., Między tacnowiernościa a niewiernościa. Diabet, magia i czary $w$ „Nowych Atenach” i „Diable w swojej postaci”, Warszawa 2014.

Miodunka P., Kryzysy żywnościowe a anomalie klimatyczne od XVII do potowy XIX wieku na przyktadzie Matopolski, „Historyka. Studia Metodologiczne” 2016, t. XLVI, s. 209-227.

Moeglich M., Procesy o czary przed sadem miejskim wagrowieckim - chronologia i dynamika zjawiska, [w:] Wangrovieciana studia et fontes. Wagrowieckie studia muzealne, red. M. Moeglich, M. Krzepkowski, t. III, Wągrowiec 2016, s. 44-91. 
Muchembled R., Le Roi et la Sorcière. L'Europe des bûchers XVe-XVIIIe siècle, Paris 1993.

Odrzywolska A., Praktyki magiczne w XVI w. i ich kontekst kulturowy, „Klio” 2020, t. LIII, nr 2, s. 107-132.

Osiński Z., Zabobon, przesą, diabty, czarownice i wilkotaki w pamiętnikach polskich z XVI i XVII wieku, „Annales Universitatis Mariae Curie-Skłodowska, sectio F - Historia” 2003, vol. LVIII, s. 59-72.

Ostling M., Between the Devil and the Host. Imagining Witchcraft in Early Modern Poland, Oxford 2011.

Ostling M., Nieznany proces o czary i świętokradztwo w Lublinie w 1644 roku, „Lud” 2005, t. LXXXIX, s. 191-203.

Pilaszek M., Litewskie procesy czarownic w XVI-XVIII w., „Odrodzenie i Reformacja w Polsce” 2002, t. XLVI, s. 7-35.

Pilaszek M., Procesy o czary w Polsce w wiekach XV-XVIII, Kraków 2008.

Popiołek B., Dobrodziejki i klienci. Specyfika patronatu kobiecego i relacji klientalnych $w$ czasach saskich, Wilanów 2020.

Popiołek B., Kobiecy świat w czasach Augusta III. Studia z mentalności kobiet z kręgów szlacheckich, Kraków 2003.

Raubo A., Pojęcie kompleksji a teoria humoralna w piśmiennictwie renesansu, „Ruch Literacki. Dwumiesięcznik" 2016, t. LVII, z. 4, s. 409-425.

Roper L., Oedipus and the Devil. Witchcraft, Sexuality and Religion in Early Modern Europe, London-New York 1994.

Salmonowicz S., Procesy o czary w Polsce. Próba rozważań modelowych, [w:] Prawo wczoraj $i$ dzis. Studia dedykowane profesor Katarzynie Sójce-Zielińskiej, red. G. Bałtruszajtys, Warszawa 2000, s. 303-321.

Sawicki M., "Co to sa czary? Co za znaki ich?” Litewskie kazanie i sposoby na czary z końca XVII i XVIII w., „Studia Historyczne” 2018, t. LXI, z. 3(243), s. 17-32.

Sawicki M., Czarownica oczami litewskiej szlachty. Dwa procesy o czary w Wielkim Księstwie Litewskim w 1631 i 1641 r., [w:] Staropolski oglad świata. Sarmacki sensualizm, red. F. Wolański, Toruń 2017, s. 59-73.

Schulte R., Man as Witch: Male Witches in Central Europe, New York 2009.

Sochaniewicz K., O potrzebie systematycznego wydawnictwa materiatów do historii procesów o czary w Polsce: referat wygtoszony na XII Zjeździe Lekarzy i Przyrodników w Warszawie, „Lud” 1925, t. XXIV, s. 165-169.

Targosz K., Sawantki w Polsce XVII w. Aspiracje intelektualne kobiet ze środowisk dworskich, Warszawa 1997.

Węglorz J., Zdrowie, choroba i lecznictwo w spoteczeństwie Rzeczypospolitej XVI-XVIII wieku, Toruń 2015.

Wijaczka J., „Czarownice” w dobrach miejskich Gdańska w czasach wczesnonowożytnych, [w:] Kobiety w Prusach Królewskich, red. W. Zawadzki, Pelplin 2020, s. 39-54.

Wijaczka J., Magia i czary. Polowanie na czarownice i czarowników w Prusach Książęcych w czasach wczesnonowożytnych, Toruń 2008. 
Wijaczka J., Mężczyźni jako ofiary procesów o czary przed sądem tobżenickim w drugiej potowie XVIII wieku, „Czasy Nowożytne” 2004, t. XVII, s. 17-30.

Wijaczka J., Oskarżenia i procesy o czary w Koźminie w XVII-XVIII wieku, „Roczniki Historyczne” 2016, t. LXXXII, s. 197-219.

Wijaczka J., Proces o czary we wsi Mtotkowo w 1692 roku. Przyczynek do polowania na czarownice w Rzeczypospolitej z XVII wieku, „Odrodzenie i Reformacja w Polsce” 2004, t. XLVIII, s. $161-170$.

Wijaczka J., Proces o czary we wsi Osowo z 1686 roku, „Czasy Nowożytne” 2011, t. XXIV, s. 221-230.

Wijaczka J., Procesy o czary przed sadem sottysim Kowalewa (Pomorskiego) w XVII-XVIII wieku, „Zapiski Historyczne” 2017, t. LXXXII, z. 2, s. 101-119.

Wijaczka J., Procesy o czary w Gdańsku w XVI-XVII wieku, „Przegląd Historyczny” 2019, t. CX, z. 3, s. 399-417.

Wijaczka J., Procesy o czary w Królewcu w XVI-XVIII wieku, [w:] Zjawiska magiczno-demoniczne na terenie dawnych ziem pruskich na tle porównawczym, red. K. Grążawski, t. II, Olsztyn 2019, s. 207-221.

Wijaczka J., Procesy o czary w Polsce w dobie Oświecenia. Zarys problematyki, „Klio” 2005, t. VII, s. 17-62.

Wijaczka J., Procesy o czary w Prusach Książecych (Brandenburskich) w XVI-XVIII wieku, Toruń 2007.

Wijaczka J., Procesy o czary w regionie świętokrzyskim w XVII-XVIII wieku, [w:] Z przesztości regionu świętokrzyskiego od XVI do XX wieku, red. J. Wijaczka, Kielce 2003, s. 37-72.

Wijaczka J., Procesy o czary w Wielkopolsce w XVI-XVIII wieku, „Czas Przeszły. Poznańskie Studia Historyczne" 2017, t. IV, s. 177-190.

Wijaczka J., Próba zimnej wody (ptawienie) w oskarżeniach i procesach o czary w państwie polsko-litewskim w XVI-XVIII wieku, „Odrodzenie i Reformacja w Polsce” 2016, t. LX, s. 73-110.

Wijaczka J., Próba zimnej wody (ptawienie) w procesach o czary we wczesnonowożytnej Europie, „Klio” 2020, t. LIII, nr 2, s. 19-66.

Wiślicz T., Fabrykacja nierządnicy, czyli o ofiarach względnej swobody seksualnej na polskiej wsi przedrozbiorowej, „Lud” 2017, t. CI, s. 129-148.

Wiślicz T., Gest obraźliwy na wsi polskiej w XVII i XVIII wieku, „Przegląd Historyczny” 1997, t. LXXXVIII, z. 3-4, s. 417-425.

Wiślicz T., Igraszki z diabtem. Procesy o czary w Rzeczypospolitej, [w:] Sekrety historii Polski. Tego nie uczyli nas w szkole, red. Z. Klimaszewska, Warszawa 2003, s. 174-177.

Wiślicz T., Spoteczeństwo Kleczewa i okolic w walce z czartem (1624-1700), „Kwartalnik Historyczny" 2004, nr 2, s. 37-60.

Wiślicz T., Talking to the Devil in the Early Modern Popular Imagination, [w:] Faith and Fantasy in the Renaissance. Texts, Images, and Religious Practices, eds O. Zorzi Pugliese, E.M. Kavaler, Toronto 2009, s. 135-146.

Wiślicz T., The Township of Kleczew and its Neighbourhood Fighting the Devil (1624-1700), „Acta Poloniae Historica” 2004, t. LXXXIX, s. 65-95. 
Wiślicz T., Tto spoteczne procesów o czary w Kleczewie i okolicy. Próba ujęcia liczbowego, [w:] Cywilizacja prowincji Rzeczypospolitej szlacheckiej, red. A. Jankowski, A. Klonder, Bydgoszcz 2004, s. 229-244.

Wiślicz T., Upodobanie. Matżeństwo i zwiazki nieformalne na wsi polskiej XVII-XVIII wieku. Wyobrażenia spoteczne i jednostkowe doświadczenia, Wrocław 2012.

Wiślicz T., Z zagadnień obyczajowości seksualnej chtopów w Polsce XVI-XVIII wieku. Przyzwolenie i penalizacja, „Lud” 2004, t. LXXXVIII, s. 41-63.

Wiślicz T., Zarobić na duszne zbawienie. Religijność chtopów matopolskich od potowy XVI do końca XVIII wieku, Warszawa 2001.

Wyporska W., Witchcraft in Early Modern Poland, 1500-1800, London 2013.

Zdziechiewicz A., Obraz kobiety w staropolskich popularnych poradnikach medycznych, „Napis” 2003, seria 9, s. 5-30.

Ziober A., Spoteczno-ekonomiczne uwarunkowania oskarżeń o czary w Wielkim Księstwie Litewskim w XVII wieku. Przyczynek do badań, „Klio” 2020, t. LIII, nr 2, s. 133-150.

Zjawiska magiczno-demoniczne na terenie dawnych ziem pruskich na tle porównawczym, red. K. Grążawski i J. Gancewski, Olsztyn 2015.

\section{Notka o autorce:}

dr hab. Bernadetta Manyś, prof. UAM - zatrudniona w Zakładzie Historii Nowożytnej do XVIII w. na Wydziale Historii Uniwersytetu im. Adama Mickiewicza, członek Polskiego Towarzystwa Historycznego, Polskiego Towarzystwa do Badań nad Wiekiem Osiemnastym oraz Poznańskiego Towarzystwa Przyjaciół Nauk.

Zainteresowania badawcze: historia Wielkiego Księstwa Litewskiego ze szczególnym uwzględnieniem historii miasta Wilna, historia kobiet, historia obyczajowości, historia kultury materialnej.

( 